\title{
A diagnostic procedure for applying the social-ecological systems framework in diverse cases
}

\author{
$\underline{\text { Jochen Hinkel }}^{1}$, Michael E. Cox ${ }^{2}$, Maja Schlüter $^{3}$, Claudia R. Binder $^{4}$ and Thomas Falk $^{5}$
}

\begin{abstract}
The framework for analyzing sustainability of social-ecological systems (SES) framework of Elinor Ostrom is a multitier collection of concepts and variables that have proven to be relevant for understanding outcomes in diverse SES. The first tier of this framework includes the concepts resource system (RS) and resource units (RU), which are then further characterized through lower tier variables such as clarity of system boundaries and mobility. The long-term goal of framework development is to derive conclusions about which combinations of variables explain outcomes across diverse types of SES. This will only be possible if the concepts and variables of the framework can be made operational unambiguously for the different types of SES, which, however, remains a challenge. Reasons for this are that case studies examine other types of RS than those for which the framework has been developed or consider RS for which different actors obtain different kinds of RU. We explore these difficulties and relate them to antecedent work on commonpool resources and public goods. We propose a diagnostic procedure which resolves some of these difficulties by establishing a sequence of questions that facilitate the step-wise and unambiguous application of the SES framework to a given case. The questions relate to the actors benefiting from the SES, the collective goods involved in the generation of those benefits, and the action situations in which the collective goods are provided and appropriated. We illustrate the diagnostic procedure for four case studies in the context of irrigated agriculture in New Mexico, common property meadows in the Swiss Alps, recreational fishery in Germany, and energy regions in Austria. We conclude that the current SES framework has limitations when applied to complex, multiuse SES, because it does not sufficiently capture the actor interdependencies introduced through RS and RU characteristics and dynamics.
\end{abstract}

Key Words: common-pool resource; commons; complex commons; public good; resource system; resource unit; SES; social-ecological system; social-ecological system framework; sustainability

\section{INTRODUCTION}

The framework for analyzing sustainability of social-ecological systems (SES framework; Ostrom 2007, 2009) is a multitier hierarchy of concepts and variables that have been identified through extensive empirical analyses of a large number of case studies in the context of fishery, water, and forestry common-pool resources (McGinnis and Ostrom 2014). On the first tier, the SES framework decomposes social-ecological systems (SES) into the six concepts of resource system (RS), resource units (RU), governance system (GS), actors (A), interactions (I) and outcomes (O). Lower tiers, i.e., second, third, fourth, etc., decompose higher-tier concepts further into more fine-grained variables (Fig. 1). For instance, RU is decomposed into resource unit mobility, replacement rate, economic value, and size. The variables have been included in the framework because they have proven useful for explaining outcomes of resource use in empirical analyses. Variables attributed to RS and RU, for example, are relevant for understanding outcomes because of the challenges that underlying biophysical or ecological characteristics of the SES can pose for collective action and governance. The variable "resource unit mobility"(RU1), for example, is important because mobile resource units such as fish present challenges in establishing ownership, responsibility, and accountability in resource use, which in turn increases the likelihood of overexploitation (Ostrom 2007).

The long-term goal of this framework is to facilitate the accumulation of knowledge and to build theory across diverse cases (Ostrom 2007, 2009). Toward this end, the SES framework has been used for conducting large- $\mathrm{N}$ studies and compiling databases to derive conclusions from diverse cases (Poteete and Ostrom 2008, Frey and Rusch 2013). Framework applications have thereby also gone beyond the classical types of resources for which the framework was originally developed. The original SES framework was designed to analyze settings where one group of resource users is extracting units of a common resource stock, as found, for example, in fishery, water, and forestry common-pool resources. SES framework applications have, however, also progressed toward more complex SES in which different types of actors obtain multiple goods and services from the SES. Examples include urban commons (Nagendra and Ostrom 2014) and recreational fisheries (Hunt et al. 2013, Schlüter et al. 2014).

Is it feasible and justified to compare diverse types of SES and to apply the framework to settings other than those for which it has been originally developed? Generalizing the SES framework beyond its original focus on common-pool resource and accumulating insights concerning the sustainability of SES across diverse cases is only meaningful if the framework's concepts and variables can be made operational unambiguously across different types of SES. Various papers in this Special feature of Ecology and Society have, however, shown that the interpretation of the concepts RS and RU and their attributed variables is not a straightforward exercise. Consider, for example, a meadow used by farmers to graze their cows. In this case, one could either consider the cow to be the RU or the grass to be the RU and the cow to be representing the second-tier variable "technology used" (A9 in Fig 1) for harvesting RU. There is no clearly superior argument for either of these alternatives.

We aim at exploring the generalization of the SES framework and at resolving some of the ambiguities in making its concepts operational. We focus on the first-tier concepts of RS and RU. This does not imply that we consider actor and governance system

${ }^{1}$ Global Climate Forum (GCF), Berlin, Germany, ${ }^{2}$ Environmental Studies Program, Dartmouth College, New Hampshire, ${ }^{3}$ Stockholm Resilience Centre, Stockholm University, Stockholm, Sweden, ${ }^{4}$ University of Munich, Germany, ${ }^{5}$ University of Marburg, Germany 
Fig. 1. The first- and second-tier concepts of the Ostrom (2009) social-ecological systems (SES) framework including minor refinements made by McGinnis and Ostrom (2014).

Social, Economic, and Political Settings (S)

S1- Economic development. S2- Demographic trends. S3- Political stability. S4- Other governance systems. S5- Markets. S6- Media organizations. S7- Technology.

Resource Systems (RS)

RS1- Sector (e.g., water, forests, pasture, fish)

RS2- Clarity of system boundaries

RS3- Size of resource system

RS4- Human-constructed facilities

RS5- Productivity of system

RS6- Equilibrium properties

RS7- Predictability of system dynamics

RS8- Storage characteristics

RS9- Location

Resource Units (RU)

RU1- Resource unit mobility

RU2- Growth or replacement rate

RU3- Interaction among resource units

RU4- Economic value

RU5- Number of units

RU6- Distinctive characteristics

RU7- Spatial and temporal distribution

\section{Action Situations: Interactions (I)}

Activities and Processes:

I1- Harvesting levels

I2- Information sharing

I3- Deliberation processes

I4- Conflicts

I5- Investment activities

I6- Lobbying activities

I7- Self-organizing activities

I8- Networking activities

I9- Monitoring activities

I10-Evaluative activities
Governance Systems (GS)

GS1- Government organizations

GS2- Nongovernment organizations

GS3- Network structure

GS4- Property-rights systems

GS5- Operational rules

GS6- Collective-choice rules

GS7- Constitutional rules

GS8- Monitoring and sanctioning rules

Actors (A)

A1- Number of relevant actors

A2- Socioeconomic attributes

A3- History or past experiences

A4- Location

A5- Leadership/entrepreneurship

A6- Norms (trust-reciprocity)/social capital

A7- Knowledge of SES/mental models

A8- Importance of resource (dependence)

A9- Technologies available

$\rightarrow$ Outcomes (O)

Outcome Criteria:

01- Social performance measures

(e.g., efficiency, equity, accountability, sustainability)

02- Ecological performance measures

(e.g., overharvested, resilience, biodiversity, sustainability)

03- Externalities to other SESs

Related Ecosystems (ECO)

ECO1- Climate patterns. ECO2- Pollution patterns. ECO3- Flows into and out of focal SES.

variables to be less important, but RS and RU define what is called "focal action situation" in the SES framework and thus form the starting point for SES framework application (McGinnis and Ostrom 2014). Our goal is to establish a diagnostic procedure in the form of a sequence of questions that facilitates the step-wise and consistent application of the SES framework in a given case. The SES framework comes along as a long list of concepts and variables that naturally raises the question where to start applying these. From our experiences in teaching and supervising $\mathrm{PhD}$ and Master's students we know that this is actually one of the greatest difficulty students face in using the framework. In this paper we fill this gap by providing a sequence of questions that build upon each-other and subsequently lead through the interpretation and application of the various concepts and variables of the framework.

We develop this procedure iteratively by applying it to the following four cases: (1) Acequia irrigated agriculture in New Mexico, (2) common property meadows in the Swiss Alps, (3) recreational fishery in Germany, and (4) Austrian energy regions. We selected cases of which we have first-hand knowledge to be able to account for all subtleties of real world SES framework application. Further, we choose the cases to be diverse and cover the spectrum from classical common-pool resource extraction 
(irrigated agriculture) to recreational benefits (recreational fishery), multiuse commons (common property meadows in the Swiss Alps), and finally socio-technical commons (Austrian energy regions).

\section{BACKGROUND}

For the development of a diagnostic procedure for the identification of RS and RU variables in different SES cases, it is useful to revisit the origins of the SES framework. The framework was originally developed for situations in which resource users extract RU from a common stock of RU, which was in turn associated with a RS (McGinnis and Ostrom 2014). The precursor to this is a large set of work on common-pool resources, particularly on fishery, forestry, and water management (Gardner et al. 1990, Ostrom et al. 1994). A common-pool resource is defined as a resource with two characteristics: (1) subtractability and (2) low excludability. Subtractability means that one user's consumption of a resource subtracts from what is available to others. Low excludability means that it is difficult to prevent nonusers from consuming the resource or otherwise imposing obligations on those who use it. Binary variations along these two dimensions have traditionally been used to create the typology of goods provided in Table 1.

Table 1. Typology of goods.

\begin{tabular}{lcc}
\hline & High excludability & Low excludability \\
\hline High subtractability & Private good & Common-pool resource \\
Low subtractability & Toll good & Public good \\
& & \\
\hline
\end{tabular}

The motivation for such a typology is to explore what governance challenges arise and which governance arrangements might be most effective in managing each type of good. Traditionally, private goods are viewed as being optimally managed by markets or private property rights, while common-pool resources and public goods provide more of a justification for common and public property and management, respectively (e.g., Vatn 2005, Weimer and Vining 2005). The reason for this is that commonpool resources and public goods create governance challenges through what are known as externalities or collective-action problems, which occur when public interests diverge from shortterm private interests. Public goods create public good provision problems, such as maintaining irrigation infrastructure, where participants must be incentivized not to free-ride on the efforts of others to provide the public good. Common-pool resources, meanwhile, produce appropriation problems, such as overfishing, where participants must be incentivized to temper their consumption of an exhaustible resource.

Although this previous work is helpful as a basis for the development of the framework, the basic typology of goods suffers from several weaknesses. To begin, in practice each dimension (subtractability, excludability) fluctuates along a continuum. The line between common-pool resources and public goods is a fuzzy one, being delineated by their differences in the dimension of subtractability, and economists sometimes finesse this issue by talking about the "congestability" of public goods (Weimer and Vining 2005), which amounts to stating that some goods have thresholds of use above which their use is subtractable, and below which it is less so, such as traffic on highways. This is really no different than the subtractability of common-pool resources such as fish in a lake: if a fisherman takes only so much that the fish can regenerate, then this use is not very subtractable. This highlights another weakness of the typology of goods: the attribute of subtractability is specific to a period of time. Regarding excludability, similar comments can be made: it is more a continuum than a binary distinction, and it is not only an inherent feature of a resource but also a feature of a relationship between the resource and other important factors such us available technologies or financial and physical resources.

These issues illustrate that it is difficult to use the typology of goods as a basis for characterizing the governance challenges associated with a given good as well as for teasing out what might be the most effective governance structure for it. The SES framework has moved beyond the simple typology of goods and the simple association of governance arrangements to these types of goods in that it considers more attributes of RS and RU beyond subtractability and excludability. The extended list of attributes fulfills the same role as the typology of goods: they help us to better understand the governance challenges that arise in SES and to understand which governance arrangements are effective for preserving the SES. The core idea therefore is that RS and RU variables characterize the kind of interdependence between actors that arise through interactions mediated via a biophysical system (Anderies et al. 2004). Table 2 illustrates this for exemplary RS and RU variables.

Table 2. The role of diverse variables of the social-ecological systems framework in contributing to the likelihood of selforganizing to prevent overexploitation of the resource system (RS). RU = resource units.

\begin{tabular}{ll}
\hline \hline RS and RU variables & $\begin{array}{l}\text { Outcomes: Likelihood of self-organization } \\
\text { (LOSO) to prevent overexploitation }\end{array}$ \\
\hline
\end{tabular}

Size of resource system For large RS the LOSO is low because of (RS3)

\section{the high cost of defining boundaries,} monitoring usage, and gaining ecological knowledge. For small RS, LOSO is low because of the little RU generated (Ostrom 2009).

Predictability of system If predictability is low, then the LOSO is dynamics (RS7) also low, because then users cannot foresee how self-organization would help them to maintain income from the RS (Ostrom 2009).

Resource unit mobility If RU are mobile, then the LOSO decreases, (RU1) because it is more difficult to establish ownership, responsibility, and accountability for the use of the RU (Ostrom 2007).

Economic values (RU4) If RU have high economic value, then the LOSO may increase or decrease, depending on other factors (Ostrom 2007).

Distinctive markings If RU naturally have or can artificially be (RU6) marked distinctively, then it is easier to establish effective property rights and the LOSO increases (Ostrom 2007). 
Table 3. Diagnostic procedure.

\begin{tabular}{ll}
\hline \hline Step & Question \\
\hline 1 & $\begin{array}{l}\text { What is the research question? Social-ecological systems (SES; or any other systems) can only be conceptualized with respect to a research } \\
\text { question. The question is needed to reduce the complexity of the SES to certain collective goods and the action situations most relevant } \\
\text { for answering the question, i.e., delineate the system's boundaries. It also determines the outcomes of interest and the level of aggregation } \\
\text { at which the system should be analyzed (Schlüter et al. 2014). All the subsequent questions of the procedure need to be answered with } \\
\text { respect to the research question. }\end{array}$ \\
Which actors (A) obtain which benefits from the SES? Benefits are understood widely, including instrumental, moral, aesthetic values, \\
current vs. future values, direct vs. indirect values, option values, etc. \\
Which collective goods are involved in the generation of these benefits? Several goods may be involved in the generation of a single benefit \\
and several of these may be collective. For example, the benefit of recreational angling may involve the collective goods "catching fish" as \\
well as "enjoying an undisturbed place for angling." \\
Are any of the collective goods obtained subtractable? If so, an appropriation action situation arises where activities subtract from a stock \\
of resource units (RU). For nonsubtractable goods there is no need to consider the variables of the RU.
\end{tabular}

\section{DIAGNOSTIC PROCEDURE}

The discussion so far has consequences for the interpretation of RS and RU and the variables associated with these in the SES framework. First, we subsume public goods and common-pool resources within a broader category of collective goods, and define these as goods and services that have nontrivial costs of exclusion, irrespective of institutional arrangements.

Second, framework interpretation is not about interpreting variables per se, but about interpreting variables in accordance with their role in explaining outcomes. The general role of RS/ RU variables is to characterize governance challenges in relation to two types of canonical action situations: (1) Provisioning action situation: those in which users face a collective challenge to create, maintain, or improve a collective good. An example would be farmers maintaining a common irrigation system. (2) Appropriation action situation: those in which actors face a collective challenge to avoid the overuse of a collective good. An example would be farmers appropriating water from a common irrigation system. Note that generally, SES analysis must consider further action situations such as those of monitoring or collective and constitutional choice, but because these do not have a direct implication for how to make RS/RU variables operational, we do not address them in this paper.

We interpret appropriation action situation in a sense wider than its original one, because we also wish to include what was called congestible public goods above, e.g., using a road or enjoying a lake for recreational purposes. Here, we define appropriation action situation to consist of actors carrying out activities that (1) depend upon a common stock, and (2) subtract from that stock. Only pure public goods (with zero subtractability) are excluded from this definition.
Originally, the SES framework considered extraction of RU as the only kind of activity that affected a stock of RU. This blurred the distinction between the stock and the activity of extracting units from it. Consequently, the stock was considered to be a common-pool resource, a collective and subtractable good. This is in line with the classical interpretation of natural resource goods in resource economics, where resources are tangible components of nature used as inputs to economic transformation processes (Vatn 2005).

When, however, considering other activities that affect and are affected by the stock (beyond extracting RU), it turns out that defining just the stock to be a subtractable collective good is not useful, because a stock is not subtractable per se, but only in relation to a certain activity. Considering a fish stock, for example, the activity of commercial fishing subtracts fully from the stock, while recreational angling might only do so partially because fish are often returned to the lake after having been caught. Further, the activity of simply watching the fish stock in a clear water lake may not subtract at all from the stock and hence there is no appropriation action situation. Similar arguments apply for excludability: the cost of excluding people from angling may be lower than the cost of excluding people from watching the fish stock. Here, we thus consider the stock together with an activity of using, consuming or enjoying the stock to be the collective good of interest for SES framework application.

Finally, the distinction between stocks of RU and the RS needs some attention. In the SES framework the two concepts are closely linked in a one-to-one relationship: One set of RU belongs to one RS (Ostrom 2007, Hinkel et al. 2014). Here, we generalize this and define the RS to be the biophysical and technological processes that create, maintain and improve stocks of RU. One 
Fig. 2. Appropriation and provisioning action situations for the Acequia irrigated agriculture in New Mexico. $\mathrm{RU}=$ resource units, $\mathrm{RS}=$ resource system.

\begin{tabular}{|l|l|l|l|l|l|l|}
\hline Actors & Benefit & Activity & Stock of RU & Subtractability & RS & $\begin{array}{l}\text { Provisioning action } \\
\text { situation }\end{array}$ \\
\hline Farmers & $\begin{array}{l}\text { Water for } \\
\text { farming }\end{array}$ & $\begin{array}{l}\text { Extracting } \\
\text { water }\end{array}$ & $\begin{array}{l}\text { Water quantity } \\
\text { available in the } \\
\text { irrigation system }\end{array}$ & High & $\begin{array}{l}\text { Hydrological system } \\
\text { and irrigation } \\
\text { infrastructure. }\end{array}$ & $\begin{array}{l}\text { Acequias (A) maintain } \\
\text { irrigation } \\
\text { infrastructure (RS4). }\end{array}$ \\
\hline
\end{tabular}

RS may thus include several interacting stocks of different kinds of units. The essential difference between RU and RS in our refinement is that the former is a stock and the latter is a set of processes (or flows) relating the stocks. This is in line with Ostrom's earlier definition that the RS “creates the conditions for the existence of a stock of resource units" (Ostrom et al. 1994:8).

We turned these insights into a procedure in the form of a sequence of questions that can be applied as a step-by-step methodology for conceptualizing SES and analyzing governance challenges using the SES framework (Table 3). This procedure starts with general questions about the context and motivation and proceeds with more specific questions regarding the action situations involved.

\section{CASE APPLICATIONS}

\section{Acequia irrigated agriculture in New Mexico}

The acequia farmers in northern New Mexico are the descendants of the Spanish colonists who moved north along the Rio Grande from Mexico beginning around 1600 . They brought with them several Spanish irrigation traditions, most importantly the institutional regime of common property (Rivera 1998). Water within each acequia is considered common property, and compliance with community obligations is required for an individual to maintain his/her individual water rights. Each farmer belongs to an acequia and there are roughly 51 acequias in Taos valley, each with an average of around 40 members.

Each acequia has a well-defined government, led by a mayordomo and three commissioners. The mayordomo decides how water is distributed within his or her acequia and monitors for infractions. The commissioners serve several administrative, legislative, and judicial roles. They are frequently called on to arbitrate disputes and support the mayordomo in enforcing ditch rules. The acequias in Taos valley in northern New Mexico, which is the focus of this case application, have sustained themselves as self-sufficient irrigation systems for hundreds of years by adapting to high desert conditions and inevitable periods of drought. This leads us to the first step in the diagnostic procedure: the research question (see Cox 2014 for a more in depth application of the SES framework to the Taos acequias).

Research question: Which social and biophysical properties have enabled the Taos acequia SES to historically persist in the face of droughts and general environmental scarcity?

Appropriation action situation characterized through RS/RU variables: The focal appropriation action situation is the classical one of extracting water from a common stock, which is done by all of the acequia farmers (Fig. 2). The use of water for irrigation is fairly subtractable, although the acequias do return a portion of the water to the main canal or river from which they extract it. The RU (water stock) is mobile (RU1) and highly spatially and temporally heterogeneous (RU7), which increases the cost of extraction and monitoring.

Institutional response to appropriation action situation: Acequias have a multilevel governance structure (GS3) enabled by key actors (the mayordomos and commissioners) that provide leadership roles within acequias, and act as bridging agents between them to support larger-scale collective action. Water rights are given proportionally to farmers as they contribute to community obligations. Finally, a decentralized monitoring system (GS8) enabled by geographic proximity (U4) and property rights arrangements (GS4) is also important. Farmers automatically monitor their neighbors when it is their turn to irrigate in a rotational rights system, and when water does not reach their ditch they have little trouble "walking up the ditch" to find out who is taking water out of turn.

Provisioning action situation characterized through RS/RU variables: The resource system is the hydrological system together with the network of irrigation canals and headgates that the acequias use to manage and direct their water. Without the irrigation infrastructure (RS4), there would not be sufficient water for all farmers, because the storage characteristic (RS8) and the productivity (RS5) of the RS are low. Collective action is necessary, because no single farmer could maintain the infrastructure alone.

Institutional response to provisioning action situation: Maintenance is organized using property rights (GS4) that proportion maintenance duties to the amount of water extraction rights. Acequia leaders (A5) lead and monitor maintenance tasks.

\section{Common property meadows in the Swiss Alps}

The common property meadows in the Swiss Alps provide important services such as income sources for farmers via direct use as well as through tourism, protection from soil erosion, water runoff, and landslides, and high biodiversity (Tasser et al. 2007; Biodiversitäts-Monitoring Schweiz, http://www.biodiversitymonitoring. $\underline{\mathrm{ch} /)}$. These services are highly dependent on continuous management of the alpine meadows. In Switzerland, most alpine summer pastures are common property and have been managed by local governance systems since the Middle Ages. Today, farmers collectively produce milk and cheese, which is distributed to individual farmers. Societal changes, like industrialization, rapid economic growth, and new agricultural policies, such as changes in the subsidy system, have induced major transitions of the pasture management system, leading to either intensification 
Fig. 3. Appropriation and provisioning action situations for common property meadows in the Swiss Alps. RU $=$ resource units, $\mathrm{RS}=$ resource system .

\begin{tabular}{|c|c|c|c|c|c|c|}
\hline Actors & Benefit & Activity & Stock of RU & Subtractability & RS & $\begin{array}{l}\text { Provisioning action } \\
\text { situation }\end{array}$ \\
\hline \multirow[t]{2}{*}{ Farmers } & $\begin{array}{l}\text { Income } \\
\text { from } \\
\text { tourism }\end{array}$ & $\begin{array}{l}\text { Selling } \\
\text { products to } \\
\text { tourists }\end{array}$ & $\begin{array}{l}\text { Total expenditure } \\
\text { of tourists }\end{array}$ & Medium & \multirow{4}{*}{$\begin{array}{l}\text { Meadow and } \\
\text { infrastructure } \\
\text { such as barns, } \\
\text { fences, milk } \\
\text { production } \\
\text { technology, } \\
\text { etc. }\end{array}$} & \multirow{4}{*}{$\begin{array}{l}\text { Farmers maintain the } \\
\text { meadows by maintaining } \\
\text { barns and fences as well as } \\
\text { by ensuring a harvesting } \\
\text { level sufficiently high to } \\
\text { prevent the natural } \\
\text { succession of meadow to } \\
\text { forest. }\end{array}$} \\
\hline & $\begin{array}{l}\text { Income } \\
\text { from } \\
\text { farming }\end{array}$ & $\begin{array}{l}\text { Extracting } \\
\text { grass }\end{array}$ & \multirow[t]{2}{*}{$\begin{array}{l}\text { The grass of the } \\
\text { meadow }\end{array}$} & High & & \\
\hline \multirow[t]{2}{*}{ Tourists } & \multirow[t]{2}{*}{ Recreation } & \multirow{2}{*}{$\begin{array}{l}\text { Enjoying } \\
\text { the } \\
\text { landscape }\end{array}$} & & No & & \\
\hline & & & $\begin{array}{l}\text { Locations for } \\
\text { enjoying the } \\
\text { landscape }\end{array}$ & Medium & & \\
\hline
\end{tabular}

or abandonment of land with an associated loss of meadows and their biodiversity. At the same time, local farmers' major source of income has shifted from farming to tourism, with tourists being attracted by the beautiful cultural landscape of the meadows. For a comprehensive treatment of this case see Baur and Binder (2013).

Research question: How have the local governance systems of common property meadows in the Swiss Alps adapted to deal with societal changes?

Appropriation action situation characterized through RS/RU variables: For this case, we identified three collective goods to be relevant (Fig. 3). For the appropriation of grass, the interpretation of RU variables is straightforward. Grass is not mobile (RU1), has a growth rate (RU2), and a spatial/temporal distribution (RU7). We did not consider the appropriation of milk and cheese from the collective production because this is not a collective good because excludability is high. Considering tourists arrivals as a stock is a bit unusual, but the interpretation of RU variables is also straightforward. A number of tourists (RU5) are visiting the meadows and farmers "appropriate" tourists buying accommodation, food, and drinks from them. The third appropriation action situation, tourist enjoying the landscape, depends upon two stocks: the grass of the meadow as well as the locations for enjoying the landscape. Only the second one is partially subtractable. Such dependencies are not captured in the original SES framework. Our refinement, which distinguishes between the stocks of RU and the activities of using the stocks, allows for the representation of these dependencies between multiple actors, multiple activities, and multiple stocks in, e.g., tabular format (Fig. 3).

Institutional response to appropriation action situation: For centuries local governance systems have avoided overuse of the meadows by strictly defining (1) the distribution of use rights and yield, i.e., number of cows allowed on the pastures and distribution among farmers); (2) the duties connected to the use of the resource, e.g., communal work; and (3) the sanctions for noncompliance (Netting 1981, Kissling-Näf et al. 2002, Tiefenbach and Mordasini 2006). The cheese produced is distributed to the farmers according to the relative amount of milk produced by each farmer's cows, which is measured twice a month.

The central governance challenge in this SES has, however, shifted from the appropriation action situation to the provisioning action situation of maintaining the RS by sending sufficient numbers of cows to the meadow. This is jeopardized by a constantly decreasing number of farmers in the region, leading to areas of the RS with intensive use and other areas where bush and forest growth is predominant (Baur and Binder 2013).

Provisioning action situation characterized through RS/RU variables: The RS is large (RS3) so that it cannot be maintained by a single farmer. Predictability (RS7) is relatively high, which increases the likelihood of self-organization.

Institutional response to provisioning action situation: Fees have to be paid if a farmer does not do the work allocated to sending a cow to the Alps. In order to be able to send enough cows to the meadows, the "import" of cows recently has been allowed.

\section{Recreational fishery in Germany}

Recreational fisheries are the dominant users of freshwater and major coastal fish stocks in industrialized countries (Arlinghaus and Cook 2009). In Western Germany they are managed by angling associations and local angling clubs that have the right to fish but also the duty to manage their water bodies sustainably. They regulate access and perform management activities in accordance with their fishing rights, angler preferences, angling club rules, and regional and national fisheries laws. Stocking, that is, the introduction of fish from a hatchery or a different water body into an existing fish population, is one of the most commonly applied management measures. However, its economic efficiency, social implications, and ecological effects are often not known. It is assumed that attributes of both the social system, e.g., angler preferences, and the ecological system, e.g., habitat conditions, determine the outcome of stocking measures. Whether an outcome is considered sustainable is evaluated based on ecological, social, and economic indicators, such as the replacement rate of wild fish by hatchery fish, the social welfare of the club or the economic performance. 
Fig. 4. Appropriation and provisioning action situations for recreational fisheries in Germany. RU = resource units, $\mathrm{RS}=$ resource system.

\begin{tabular}{|l|l|l|l|l|l|l|}
\hline Actors & Benefit & Activity & Stock of RU & Subtractability & RS & $\begin{array}{l}\text { Provisioning action } \\
\text { situation }\end{array}$ \\
\hline Anglers & Recreation & Catching fish & Fish stock & Medium & $\begin{array}{l}\text { Water body, } \\
\text { angling club } \\
\text { infrastructure }\end{array}$ & $\begin{array}{l}\text { Angling clubs } \\
\text { maintain the water } \\
\text { bodies and restock } \\
\text { the fish stocks. }\end{array}$ \\
\cline { 2 - 7 } & $\begin{array}{l}\text { Occupying a } \\
\text { location for } \\
\text { undisturbed } \\
\text { angling }\end{array}$ & $\begin{array}{l}\text { All available } \\
\text { angling } \\
\text { locations. }\end{array}$ & High & & & \\
\hline
\end{tabular}

Research question: Can stocking enhance the sustainability of recreational fisheries?

Appropriation action situation characterized through RS/RU variables: We have identified two subtractable collective goods and hence focal appropriation action situation relevant for the angler's benefit of recreational angling (Fig. 4). The first one is "catching fish," i.e., the appropriation of fish from the fish stock (RU) provided by the water body (RS). The fish stock is only partially subtractable as recreational anglers often benefit from catching the fish without actually harvesting and thus consuming it. Under-size fish and larger fish are often returned to the water body. This appropriation action situation is characterized by the RU being mobile (RU1) and not distinctively marked (RU6), which makes it difficult to monitor the state of the stock. If the $\mathrm{RS}$ is large (RS3) and productive (RS5), RU are less scarce and the governance challenge is smaller.

The second appropriation action situation relevant is the appropriation of an undisturbed location for enjoying the angling experience as at least some anglers benefit less if water bodies are crowded with anglers. Here, the stock of RU, i.e., the angling locations, is not mobile (RU1) and does not grow (RU2). The location (RS9) and size of the RS (RS3) can be of relevance because a larger water body that is more remote poses less governance challenges than a small water body in a densely populated region. Our generalization of the appropriation action situation allows representing these kinds of situations, which would have been difficult to capture in the classical SES framework.

Institutional response to appropriation action situation: Access restrictions through angling clubs and angling permits.

Provisioning action situation characterized through RS/RU variables: The main provision action situation relevant for the research question is stocking and the governance challenge is characterized by the difficulty of determining the optimal stocking strategy and keeping anglers from fishing out the newly stocked fish. Predictability of system dynamics (RS7) is low both because of natural variability as well as uncertainty about the effect of stocking on the fish population. The size of the fish population (RU5) is difficult to measure because of the RU's mobility (RU1) and their high spatial and temporal variability (RU7). Because of these characteristics, the perceived angling experience can be very different from the actual ecological situation, e.g., anglers think that there is not enough fish while actually fish populations are in good condition. This may lead to angling club managers being subject to social pressure from anglers. A related issue is that stocked fish can also affect other fish species, which can create conflict between anglers, e.g., between carp and other anglers. Stocking might also lead to a lack of genetic diversity that could potentially affect the longterm sustainability of the fish stocks.

Institutional response to provisioning action situation: Because of this low predictability, stocking is often carried out following habits, rules of thumb, influence of powerful anglers, or mainly to show that the angling club leadership is active without really aiming at enhancing the fish stock. Anglers have to pay club membership fees that are used to finance stocking activities. Clubs might develop rules that restrict access to newly stocked water bodies for a certain period of time. Additionally there are national and regional laws that restrict stocking of particular species or water bodies.

\section{Energy regions in Austria}

To explore the application of the SES framework to cases that are very different from those upon which it has been developed, we also provide a preliminary application to the social-technical systems (STS) of Austrian energy regions. These systems are in many respects similar to SES if one considers the technical subsystem to be the RS. Energy regions in Austria are regional initiatives, which usually envision energy self-sufficiency by decreasing energy demand and using regional renewable energy sources and building a decentralized energy infrastructure (Bundesministerium für Verkehr, Innovation und Technologie, http://www.energiesystemederzukunft.at). In Austria, energy regions have emerged since the 1990s and today there are 66 "climate and energy model regions" including 773 municipalities with 1.7 million inhabitants.

There is evidence that the transition to such model regions provides further benefits such as new jobs, the establishment of new companies, and sectors like "eco-energy tourism" and educational programs, which consequently have raised the acceptance and interest of the population (Späth 2007). Even though several studies have analyzed technical and operational issues of energy production, the relationship between the energy producing system, actors, and the governance system underlying or supporting such transformation processes have hardly been studied. This case study compares the development of two Austrian energy regions with different environmental conditions and different governance structures. The SES thereby is the basis upon which the data is collected and made comparable between these two case studies. 
Fig. 5. Appropriation and provisioning action situations for Austrian energy regions. RU = resource units, RS = resource system.

\begin{tabular}{|c|c|c|c|c|c|c|}
\hline Actors & Benefits & Activity & Stock of RU & Subtractability & RS & $\begin{array}{l}\text { Provisioning action } \\
\text { situation }\end{array}$ \\
\hline \multirow[t]{2}{*}{$\begin{array}{l}\text { Households } \\
\text { and firms }\end{array}$} & $\begin{array}{l}\text { Using } \\
\text { electricity } \\
\text { any time }\end{array}$ & $\begin{array}{l}\text { Withdrawing } \\
\text { electric } \\
\text { energy }\end{array}$ & \multirow{2}{*}{$\begin{array}{l}\text { Unused } \\
\text { capacity of } \\
\text { energy } \\
\text { conversion and } \\
\text { storage }\end{array}$} & \multirow[t]{2}{*}{ Various } & \multirow[t]{2}{*}{$\begin{array}{l}\text { Power plants, } \\
\text { power grid } \\
\text { and storage } \\
\text { infrastructure }\end{array}$} & \multirow{2}{*}{$\begin{array}{l}\text { Grid operators maintain } \\
\text { infrastructure and ensure } \\
\text { that demand and supply is } \\
\text { balanced at all times } \\
\text { through switching supply } \\
\text { and storage facilities on } \\
\text { and off. }\end{array}$} \\
\hline & $\begin{array}{l}\text { Selling } \\
\text { electricity } \\
\text { any time }\end{array}$ & $\begin{array}{l}\text { Feeding-in } \\
\text { electric } \\
\text { energy }\end{array}$ & & & & \\
\hline
\end{tabular}

Research question: Which technological and resource proprieties, as well as policies and socioeconomic processes, have shaped the transition of regions to energy regions? Which types of energy governance arrangements have emerged?

Appropriation action situation characterized through RS/RU variables: Intuitively, one could consider the appropriation action situation here to be similar to the standard resource extraction one: Households and firms (A) extract electric energy (RU) from the energy system (Fig. 5). What is distinct in this case, however, is that these actors may also feed electric energy into the electrical system. An important question is then, what is the stock of RU? It cannot be a stock of electric energy, because electric energy cannot be stored, but can only be converted into other forms of energy. Relevant stocks impacted by withdrawing and feeding-in activities are the capacities to convert energy either in the form of switching on power plants when demand increases or switching on storage facilities in the form of, say, batteries of mobile vehicles or a pumped-storage hydroelectricity. Nevertheless, the interpretation of some RS variables is straightforward. The RS is fully constructed by humans (RS4) and the system boundaries are clear (RS2). Storage is limited (RS8) with the specific equilibrium property that electric energy extracted from and fed into the grid must be equal at all times (RS6).

RU variables are more difficult to interpret. If one would consider electric energy to be the RU then the straight forward interpretation would be that this is mobile (RU1). Here, however, we consider, for reasons given above, the "unused capacity of energy conversion and storage" to be the relevant stock of RU. This stock is certainly less or not mobile with the exception of electric vehicles. This interpretation is also in line with the explanatory role that the variable mobility has in the SES framework, namely that RU mobility increases the costs of extraction and monitoring because it is difficult to know where the RU are (Ostrom 2007). Knowing where the energy is, is certainly not an issue in the case of energy feed-in, transmission, and withdrawal.

Institutional response to appropriation action situation: New over-regional governance bodies emerged (including several Gemeinden), which are responsible for the infrastructure and set the rules for the subsidy conditions at the local level.

Provisioning action situation characterized through RS/RU variables: Maintaining the RS (balance between demand and supply) has been made more difficult through the inclusion of more renewable energy producers as this decreases predictability (RS7). This may be addressed by either increasing the size of the system (RS3), which in turn increases predictability (RS7) as demand and supply are then easier to balance, or by installing additional storage capacity (RS8), both of which requires large investments.

Institutional response to provisioning action situation: Addressing the provisioning governance challenge requires the construction of an infrastructure that is able to balance the high volatility of renewable energy production. This requires investment in sufficient capacity for storage supplemented by producer/consumer agreements.

\section{DISCUSSION AND CONCLUSION}

We have presented a procedure for clearly defining RS and RU in the context of an analysis of a particular SES case. The procedure includes a set of 10 questions, which guide the interpretation and application of the SES framework through the identification of the actors involved, the benefits obtained, and the collective action situations relevant for generating these benefits. The procedure provides for a more systematic and transparent interpretation of RU and RS and selection of relevant second tier variables, thus enhancing consistency and comparability across cases as well as facilitating scientific communication. This procedure was developed and tested iteratively by applying it to diverse cases and has thereby enabled us to better compare our case studies. We also have tested and further developed this procedure through applying it to a larger number of cases together with Master's students in university courses.

The diagnostic procedure facilitates making RS and RU variables operational for nonstandard SES framework applications through two refinements to the SES framework. First, we have made explicit the distinction between stocks of RU on one hand and activities that affect the stocks on the other hand. Both the stock and the activity together should be called a common-pool resource (subtractable, collective good) and not only the former, as stocks are not subtractable per se, but only with respect to activities of enjoying, using, or consuming the stock.

Second, we interpret RU variables as referring to the stock of RU and not to individual units (see also Hinkel et al. 2014). This way, RU mobility refers to the mobility of the stock within the RS. This means that a stock of fish is highly mobile, a stock of water in an irrigation system is less mobile (i.e., the stock is constrained 
to the channels) and a stock of "unused capacity of energy conversion" in a transmission grid is hardly mobile. Heterogeneity in spatial distribution combined with high mobility exacerbates the challenge of assigning and enforcing rights and obligations with respect to a RU (Gardner et al. 1990).

Nevertheless, two major challenges for applying the SES framework to complex SES remain. First, the SES framework does not capture interdependencies in complex commons where multiple types of actors carry out multiple activities that depend on and affect multiple RU and RS. Unfortunately, given the current intensity of human-environment interactions, these complex systems are the rule rather than the exception (Steins and Edwards 1999). In this context, the SES framework does not provide means to capture how multiple uses and benefits are connected, which however is exactly what generates the governance challenges.

Second, the SES framework does not represent the dynamic aspects of RU stocks and activities of actors. For example, in the case of the activity of extracting water, the stock regenerates gradually, whereas in the case of occupying a location for angling, the stock regenerates fully and instantaneously after the activity has stopped. In the case of using electrical power, both starting and stopping the activity negatively impacts the stocks of available energy storage and conversion. The variables of the framework that relate to RS and RU dynamics, including equilibrium properties (RS6), predictability of system dynamics (RS7), storage characteristics (RS8), and growth or reproductive rate (RU2), are difficult to interpret, overlap in meanings, and do not capture these differences unambiguously. Particular challenges in making these variables operational arise because of multiple levels of ecological organization (Hinkel et al. 2014) and nonlinear and threshold dynamics that are very common in SES (Walker et al. 2004, Walker and Meyers 2004).

A further issue that arose in interpreting RS and RU variables was that some of these frequently depend on the ways in which humans have altered RS and RU through human constructed facilities (RS4). For example, the value of the variables growth or replacement rate (RS2), clarity of system boundaries (RS3), storage characteristics (RS8), distinctive characteristics (RU6), and spatial and temporal distribution (RU7) may all be altered by human interventions such as building irrigation infrastructure, constructing reservoirs, or artificially marking boundaries of RS or RU (see Appendix 1). Because these interventions alter the characteristics of the collective goods provided, it would be beneficial to know the values of these variables both with and without the intervention to be able to generalize findings across different SES. Future framework development should attempt to draw this distinction.

Addressing these challenges could imply making rather radical changes to the SES framework. In particular, when considering complex multiuse SES, it might make sense to replace RS and RU concepts with the concept of the extended appropriation action situation developed here and to further classify these appropriation action situations according to the interdependence that arises through the characteristics of the goods and services obtained within this type of action situation. The challenge thereby would be to characterize these situations with variables that fulfill the same explanatory role in diverse SES, because only then is it meaningful to compare such cases and build theory across them. Irrespective of this challenge, the current SES framework is certainly a useful entry point for SES analysis and can serve as a general language for speaking about complex SES.

Responses to this article can be read online at: http://www.ecologyandsociety.org/issues/responses. $\mathrm{php} / 7023$

\begin{abstract}
Acknowledgments:
We greatly thank Elinor Ostrom and all members of the SES Club for the enriching and exciting discussions we had at our meetings during the last couple of years. We also thank four anonymous reviewers for their helpful and constructive comments. Funding for $M S$ was provided by a starting grant from the European Research Council under the European Unions Seventh Framework Programme (FP/2007-2013)/ERC grant agreement no. 283950 SES-LINK and the German Ministry for Education and Research within the project Besatzfisch in the Program for Social-Ecological Research (Grant 01UU0907).
\end{abstract}

\section{LITERATURE CITED}

Anderies, J. M., M. A. Janssen, and E. Ostrom. 2004. A framework to analyze the robustness of social-ecological systems from an institutional perspective. Ecology and Society 9(1): 18. [online] URL: http://www.ecologyandsociety.org/vo19/iss1/art18/

Arlinghaus, R., and S. J. Cooke. 2009. Recreational fishing: socioeconomic importance, conservation issues and management challenges. Pages 39-58 in B. Dickson, J. Hutton, and B. Adams, editors. Recreational hunting, conservation and rural livelihoods. science and practice. Blackwell, Oxford, UK.

Baur, I., and C. R. Binder. 2013. Adapting to socioeconomic developments by changing rules in the governance of common property pastures in the Swiss Alps. Ecology and Society 18(4): 60. http://dx.doi.org/10.5751/ES-05689-180460

Cox, M. 2014. Applying a social-ecological system framework to the study of the Taos Valley irrigation system. Human Ecology 42:311-324. http://dx.doi.org/10.1007/s10745-014-9651-y

Frey, U. J., and H. Rusch. 2013. Using artificial neural networks for the analysis of social-ecological systems. Ecology and Society 18(2): 40. http://dx.doi.org/10.5751/ES-05202-180240

Gardner, R., E. Ostrom, and J. Walker. 1990. The nature of common-pool resource problems. Rationality and Society 2 (3):335-358. http://dx.doi.org/10.1177/1043463190002003005

Hinkel, J., P. W. G. Bots, and M. Schlüter. 2014. Enhancing the Ostrom social-ecological system framework through formalization. Ecology and Society 19(3): 51. http://dx.doi.org/10.5751/ ES-06475-190351

Hunt, L. M., S. G. Sutton, and R. Arlinghaus. 2013. Illustrating the critical role of human dimensions research for understanding and managing recreational fisheries within a social-ecological system framework. Fisheries Management and Ecology 20 (2-3):111-124. http://dx.doi.org/10.1111/j.1365-2400.2012.00870. 
Kissling-Näf, I., T. Volken, and K. Bisang. 2002. Common property and natural resources in the Alps: the decay of management structures? Forest Policy And Economics 4:135-147. http://dx.doi.org/10.1016/S1389-9341(02)00013-8

McGinnis, M. D., and E. Ostrom. 2014. Social-ecological system framework: initial changes and continuing challenges. Ecology and Society 19(2): 30. http://dx.doi.org/10.5751/ES-06387-190230

Nagendra, H., and E. Ostrom. 2014. Applying the socialecological system framework to the diagnosis of urban lake commons in Bangalore, India. Ecology and Society 19(2): 67. http://dx.doi.org/10.5751/ES-06582-190267

Netting, R. M. C. 1981. Balancing on an alp: ecological change and continuity in a Swiss mountain community. Cambridge University Press, Cambridge, UK.

Ostrom, E. 2007. A diagnostic approach for going beyond panaceas. Proceedings of the National Academy of Sciences 104 (39):15181-15187. http://dx.doi.org/10.1073/pnas.0702288104

Ostrom, E. 2009. A general framework for analyzing sustainability of social-ecological systems. Science 325 (5939):419-422. http://dx.doi.org/10.1126/science.1172133

Ostrom, E., R. Gardner, and J. Walker. 1994. Rules, games and common-pool resources. University of Michigan Press, Ann Arbor, Michigan, USA.

Poteete, A. R., and E. Ostrom. 2008. Fifteen years of empirical research on collective action in natural resource management: struggling to build large- $\mathrm{N}$ databases based on qualitative research. World Development 36(1):176-195. http://dx.doi. org/10.1016/j.worlddev.2007.02.012

Rivera, J. A. 1998. Acequia culture: water, land, and community in the Southwest. University of New Mexico Press, Albuquerque, New Mexico, USA.

Schlüter, M., J. Hinkel, P. W. G. Bots, and R. Arlinghaus. 2014. Application of the SES framework for model-based analysis of the dynamics of social-ecological systems. Ecology and Society 19(1): 36. http://dx.doi.org/10.5751/ES-05782-190136

Späth, P. 2007. “Energieregionen”: Wirksame Leitbildprozesse und Netzwerke zur regionalen Gestaltung sozio-technischen Wandels. Bundesministerium für Verkehr, Innovation und Technologie, Vienna, Austria.

Steins, N., and V. M. Edwards. 1999. Platforms for collective action in multiple-use common-pool resources. Agriculture and Human Values 16:241-255. http://dx.doi.org/10.1023/A:1007591401621

Tasser, E., J. Walde, U. Tappeiner, A. Teutsch, and W. Noggler. 2007. Land-use changes and natural reforestation in the eastern central Alps. Agriculture, Ecosystems \& Environment 118 (1-4):115-129. http://dx.doi.org/10.1016/j.agee.2006.05.004

Tiefenbach, M., and A. G. Mordasini. 2006. Bergschaften in Grindelwald. Alppflege zwischen Tradition und Moderne. Sutter Druck AG, Gindelwald, Switzerland.

Vatn, A. 2005. Institutions and the environment. Edward Elgar, Cheltenham, UK.
Walker, B., C. S. Holling, S. R. Carpenter, and A. Kinzig. 2004 Resilience, adaptability and transformability in social-ecological systems. Ecology and Society 9(2): 5. [online] URL: http://www. ecologyandsociety.org/vo19/iss2/art5/

Walker, B., and J. A. Meyers. 2004. Thresholds in ecological and social-ecological systems: a developing database. Ecology and Society 9(2): 3. [online] URL: http://www.ecologyandsociety.org/ vol9/iss $2 / \operatorname{art} 3 /$

Weimer, D. L., and A. R. Vining. 2005. Policy analysis: concepts and practice. Prentice Hall, Upper Saddle River, New Jersey USA. 
Appendix 1. Comparative interpretation of resource system (RS) and resource unit (RU) variables in the four cases.

In the table below we give for each concept or variable a general interpretation as well as case-specific ones. If several general interpretations of a single variable are perceivable, we represent these in separate rows of the table. Note that the table focuses on the interpretation of the variables and not on assigning values to them. Nevertheless, when values can be assigned, we add them in square brackets.

\begin{tabular}{|c|c|c|c|c|c|}
\hline Variable & General interpretation & $\begin{array}{c}\text { Acequia irrigated } \\
\text { agricultural in New } \\
\text { Mexico }\end{array}$ & $\begin{array}{c}\text { Common property } \\
\text { meadows in the Swiss Alps }\end{array}$ & Recreational fisheries in Germany & Energy Regions in Austria \\
\hline Actor (A) & $\begin{array}{l}\text { Those that benefit from or } \\
\text { maintain the RS }\end{array}$ & Acequia farmers & Farmers, tourists & Anglers, angling club & $\begin{array}{l}\text { Households and firms, grid } \\
\text { operator }\end{array}$ \\
\hline $\begin{array}{l}\text { Technology } \\
\text { used (A9) }\end{array}$ & $\begin{array}{l}\text { Private technology } \\
\text { involved in obtaining } \\
\text { collective goods from the } \\
\text { SES }\end{array}$ & $\begin{array}{l}\text { Pumps, sprinklers (all } \\
\text { technology used for getting } \\
\text { the water to the plant) }\end{array}$ & Cow & Fishing gear, boats & Electrical connection \\
\hline RS & & $\begin{array}{l}\text { Hydrological and irrigation } \\
\text { system }\end{array}$ & Meadow & Waterbodies & $\begin{array}{l}\text { Grid, power plants and storage } \\
\text { infrastructure }\end{array}$ \\
\hline Sector (RS1) & & Agriculture & Agriculture & Recreational fishery & Energy \\
\hline $\begin{array}{l}\text { Clarity of } \\
\text { system } \\
\text { boundaries } \\
\text { (RS2) }\end{array}$ & $\begin{array}{l}\text { Natural system boundaries } \\
\text { (before human } \\
\text { intervention) }\end{array}$ & Catchment [low] & $\begin{array}{l}\text { Vegetation zone suitable for } \\
\text { farming [high] }\end{array}$ & Coast [low] and shore [high] & [high] \\
\hline $\begin{array}{l}\text { Size of } \\
\text { resource } \\
\text { system (RS3) }\end{array}$ & & Catchment area & Area & Number or area of water bodies & $\begin{array}{l}\text { Length of the grid, capacity of } \\
\text { power plants and storage }\end{array}$ \\
\hline $\begin{array}{l}\text { Human } \\
\text { constructed } \\
\text { facilities (RS4) }\end{array}$ & $\begin{array}{l}\text { The facilities put into } \\
\text { place to provide, maintain } \\
\text { or improve the stock of } \\
\text { RU }\end{array}$ & Irrigation system & Fences, barns & Ponds, hatchery & $\begin{array}{l}\text { The RS is the human constructed } \\
\text { facility }\end{array}$ \\
\hline $\begin{array}{l}\text { Productivity of } \\
\text { system (RS5) }\end{array}$ & $\begin{array}{l}\text { The number of RU } \\
\text { produced in a certain time } \\
\text { period }\end{array}$ & $\mathrm{m}^{3} /$ time & Biomass/time & Biomass or number of fish/time & Power (electric energy/time) \\
\hline
\end{tabular}




\begin{tabular}{|c|c|c|c|c|c|c|}
\hline Variable & & General interpretation & $\begin{array}{c}\text { Acequia irrigated } \\
\text { agricultural in New } \\
\text { Mexico }\end{array}$ & $\begin{array}{c}\text { Common property } \\
\text { meadows in the Swiss Alps }\end{array}$ & Recreational fisheries in Germany & Energy Regions in Austria \\
\hline $\begin{array}{l}\text { Equilibrium } \\
\text { properties } \\
\text { (RS6) }\end{array}$ & & $\begin{array}{l}\text { Description of the } \\
\text { equilibrium dynamics of } \\
\text { the system }\end{array}$ & & & $\begin{array}{l}\text { Fish populations can collapse due to } \\
\text { over-harvesting }\end{array}$ & $\begin{array}{l}\text { Demand and supply of energy } \\
\text { must be equal in each instance }\end{array}$ \\
\hline $\begin{array}{l}\text { Predictability } \\
\text { of system } \\
\text { dynamics } \\
\text { (RS7) }\end{array}$ & & $\begin{array}{l}\text { Predictability of the } \\
\text { number of RU available at } \\
\text { a certain point in time }\end{array}$ & $\begin{array}{l}\text { Straight-forward } \\
\text { interpretation [medium] }\end{array}$ & $\begin{array}{l}\text { Straight-forward } \\
\text { interpretation [high] }\end{array}$ & Straight-forward interpretation [low] & $\begin{array}{l}\text { Predictability of energy demand } \\
\text { [high] and supply [low] }\end{array}$ \\
\hline \multirow[t]{2}{*}{$\begin{array}{l}\text { Storage } \\
\text { characteristics } \\
\text { (RS8) }\end{array}$} & I & $\begin{array}{l}\text { The ability of the RS to } \\
\text { store RU (excluding the } \\
\text { HCF) }\end{array}$ & $\begin{array}{l}\text { Retention potential of the } \\
\text { hydrological system }\end{array}$ & $\begin{array}{l}\text { Potential to store grass on the } \\
\text { meadow itself [low; grass is } \\
\text { either there or not] }\end{array}$ & $\begin{array}{l}\text { [Low] however, fish often live } \\
\text { several years and thus are somewhat } \\
\text { "stored" }\end{array}$ & $\begin{array}{l}\text { [low] Electric energy itself can } \\
\text { not be stored, but must be } \\
\text { converted into other energy } \\
\text { forms, which is costly. }\end{array}$ \\
\hline & II & $\begin{array}{l}\text { The ability of the RS to } \\
\text { store RU (including the } \\
\text { HCF) }\end{array}$ & $\begin{array}{l}\text { Retention potential of the } \\
\text { combined hydrological and } \\
\text { irrigation system }\end{array}$ & $\begin{array}{l}\text { Potential to store grass as } \\
\text { hey and to feed the hey to the } \\
\text { cows later on [medium; } \\
\text { higher than with } \\
\text { interpretation 1] }\end{array}$ & $\begin{array}{l}\text { [low] fish are very difficult to store } \\
\text { because they need to be conserved } \\
\text { which is often expensive }\end{array}$ & $\begin{array}{l}\text { E.g. pumped-storage } \\
\text { hydroelectricity [high] }\end{array}$ \\
\hline Location (RS9) & & Geographic location & $\begin{array}{l}\text { Straight-forward } \\
\text { interpretation }\end{array}$ & $\begin{array}{l}\text { Straight-forward } \\
\text { interpretation }\end{array}$ & Straight-forward interpretation & Straight-forward interpretation \\
\hline $\mathbf{R U}$ & & Stock of RU & Water flow & Grass area/biomass & Fish stock & $\begin{array}{l}\text { Energy, capacity to convert } \\
\text { energy }\end{array}$ \\
\hline Mobility (RU1) & & $\begin{array}{l}\text { The mobility of the RU } \\
\text { stock within the RS. }\end{array}$ & [medium] & [no] & $\begin{array}{l}\text { Fish can move easily between } \\
\text { different habitats within a water } \\
\text { body [high] }\end{array}$ & {$[\mathrm{no}]$} \\
\hline $\begin{array}{l}\text { Growth or } \\
\text { replacement } \\
\text { rate (RU2) }\end{array}$ & & $\begin{array}{l}\text { The rate at which RU grow } \\
\text { or are replaced after } \\
\text { having been extracted. }\end{array}$ & $\mathrm{m}^{3} /$ time & $\begin{array}{l}\text { Growth of grass } \\
\text { area/biomass }\end{array}$ & $\begin{array}{l}\text { Reproductive rate of a fish, growth } \\
\text { rate of the population }\end{array}$ & $\begin{array}{l}\text { [Infinity; RU must be replaced } \\
\text { instantaneously otherwise the } \\
\text { system collapses] }\end{array}$ \\
\hline $\begin{array}{l}\text { Interaction } \\
\text { among } \\
\text { resource units } \\
\text { (RU3) }\end{array}$ & I & $\begin{array}{l}\text { Ecological interactions } \\
\text { between same RU }\end{array}$ & No & No & $\begin{array}{l}\text { Yes, through competition, predation, } \\
\text { Canibalism. }\end{array}$ & No \\
\hline
\end{tabular}




\begin{tabular}{|c|c|c|c|c|c|c|}
\hline Variable & & General interpretation & $\begin{array}{c}\text { Acequia irrigated } \\
\text { agricultural in New } \\
\text { Mexico }\end{array}$ & $\begin{array}{c}\text { Common property } \\
\text { meadows in the Swiss Alps }\end{array}$ & Recreational fisheries in Germany & Energy Regions in Austria \\
\hline $\begin{array}{l}\text { Interaction } \\
\text { among } \\
\text { resource units } \\
\text { (RU3) }\end{array}$ & II & $\begin{array}{l}\text { Ecological interactions } \\
\text { between different RU }\end{array}$ & None relevant for the study & $\begin{array}{l}\text { Many (e.g., biomass affects } \\
\text { water run-off), but none are } \\
\text { relevant for the study. }\end{array}$ & None are relevant for the study. & No \\
\hline $\begin{array}{l}\text { Economic } \\
\text { Value (RU4) }\end{array}$ & & Use value per unit & $\begin{array}{l}\text { Straight-forward } \\
\text { interpretation }\end{array}$ & $\begin{array}{l}\text { Straight-forward } \\
\text { interpretation }\end{array}$ & $\begin{array}{l}\text { Value of fish or value of fishing } \\
\text { license. }\end{array}$ & Straight-forward interpretation \\
\hline $\begin{array}{l}\text { Number of } \\
\text { units (RU5) }\end{array}$ & & & Total amount of water $\left(\mathrm{m}^{3}\right)$ & $\begin{array}{l}\text { Area of grass or total } \\
\text { biomass }\end{array}$ & Number of fish & Power \\
\hline \multirow[t]{2}{*}{$\begin{array}{l}\text { Distinctive } \\
\text { characteristics } \\
\text { (RU6) }\end{array}$} & $\mathbf{I}$ & $\begin{array}{l}\text { Natural markings: The } \\
\text { potential to identify an } \\
\text { individual RU based on its } \\
\text { natural characteristics. }\end{array}$ & $\begin{array}{l}\text { Natural tracers } \\
\text { (bio-geo-chemical } \\
\text { composition) reveal origin } \\
\text { [somewhat] }\end{array}$ & $\begin{array}{l}\text { Since RU can not move, they } \\
\text { are marked through there } \\
\text { unique geographic location. } \\
\text { [yes] }\end{array}$ & $\begin{array}{l}\text { [no; Without anthropogenic marking, } \\
\text { the identity of a fish cannot be } \\
\text { recognized] }\end{array}$ & $\mathrm{N} / \mathrm{a}$ \\
\hline & II & $\begin{array}{l}\text { Artificial markings: The } \\
\text { potential to } \\
\text { anthropologically mark a } \\
\text { RU so that is can be } \\
\text { identified. }\end{array}$ & $\begin{array}{l}\text { Artificial tracers could be } \\
\text { added to water. [somewhat] }\end{array}$ & Same as above. & Fish can be marked with tags [yes] & $\mathrm{N} / \mathrm{a}$ \\
\hline \multirow[t]{2}{*}{$\begin{array}{l}\text { Spatial and } \\
\text { temporal } \\
\text { distribution } \\
\text { (RU7) }\end{array}$} & I & $\begin{array}{l}\text { Natural spatial and } \\
\text { temporal variability of RU. }\end{array}$ & $\begin{array}{l}\text { [high; as usually in arid } \\
\text { climates] }\end{array}$ & $\begin{array}{l}\text { Spatial and temporal } \\
\text { variability of the grass } \\
\text { (quality, biomass, growth } \\
\text { rate) }\end{array}$ & $\begin{array}{l}\text { Spatial and temporal variability of } \\
\text { fish }\end{array}$ & $\mathrm{N} / \mathrm{a}$ \\
\hline & II & $\begin{array}{l}\text { Spatial and temporal } \\
\text { variability of RU mediated } \\
\text { through } \\
\text { human-constructed } \\
\text { facilities or human } \\
\text { activities. }\end{array}$ & $\begin{array}{l}\text { Altered by irrigation system. } \\
\text { Tail and head-end } \\
\text { distribution of water in the } \\
\text { irrigation system } \\
\text { (upstream-downstream) }\end{array}$ & $\begin{array}{l}\text { Spatial and temporal } \\
\text { variability of the grass } \\
\text { altered by fertilizers, etc. }\end{array}$ & $\begin{array}{l}\text { Spatial and temporal variability of } \\
\text { fish altered by stocking }\end{array}$ & $\begin{array}{l}\text { Spatial [no] and temporal [yes] } \\
\text { variation of energy demand and } \\
\text { supply. }\end{array}$ \\
\hline
\end{tabular}

